\section{Tertiary Education and Economic Growth in Sub- Saharan Africa: The World Bank Report}

\section{William Saint}

William Saint is a coauthor of this report and an independent consultant specializing in the higher education of developing countries. Address: 3179 Colchester Brook Lane, Fairfax, VA 22031, USA. E-mail: wsaint@cox.net. This article is based on the World Bank report, "Accelerating Catch-Up: Tertiary Education and Growth in Sub-Saharan Africa."

$\mathrm{T}_{\mathrm{h}}^{\mathrm{h}}$ he emergence of a highly competitive, globally integrated, knowledge-driven world economy is reshaping traditional understandings of the role of higher education in national economic development. Economic powerhouses from Asia offer concrete evidence of what can be achieved when governments consciously seek to foster capacities for higher-level-skills development and problem-solving research, and to align them with national economic strategy objectives.

What can be learned from these and similar experiences that might be applied to sustain and strengthen the nearly 6 percent economic growth rates in much of Sub-Saharan Africa since the year 2000? This is the question that frames a new World Bank report entitled "Accelerating Catch-Up: Tertiary Education for Growth in Sub-Saharan Africa." Linking international experience, particularly from Asia, with case studies of seven African nations and nine commissioned research papers, the report argues that ratcheting up growth on the continent will require sharp gains in allocative efficiency within the public, financial, and business sectors; substantial increases in the efficiency with which capital assets are utilized; and steady improvements in local capacities to search for and assimilate relevant technologies. All of this necessitates an accumulation of managerial and organizational skills derived primarily from postsecondary education. These in turn expand capacities for innovation and the "discovery" of new export goods. In short, a strong positive relationship is found between the skills imparted through secondary and tertiary education, and export competitiveness in developing countries.

\section{Investing in Human Capital}

This argument is bolstered by an extensive review of relevant research from around the world. Notably, it highlights recent trends of rising rates of return to higher education as the demand for skilled workers strengthens in numerous countries. These trends call into question past research findings that social rates of return to higher education were lower than those for primary and secondary education and led the report to conclude: "Almost no one now doubts that modern econom- ic growth anywhere in the world is becoming more, rather than less, skill intensive, and is requiring increasingly higher levels of education, technical competence, and computer literacy" (p. 6).

The analysis softens the long-standing confrontation between basic and higher education. It affirms that both are necessary for social and economic development, the priority accorded to one or the other being dependent upon specific country circumstances. Moreover, it distances higher education from this intrasectoral competition for legitimacy (and shares of the national education budget) by showing how higher education now extends beyond its traditional role as a social service to play an important part in the drama of national economic development. From this perspective, higher education expenditures can now be justified as strategic investments in human capital formation that boost productivity and enhance national economic competitiveness.

Despite recent reform efforts and achievements by some institutions, higher education systems in sub-Saharan Africa have not yet adapted to the new rules imposed by a global knowledge economy. The report offers support for this conclusion in its assessment of progress and shortcomings in eight determinant aspects of higher education performance: strategic orientation, autonomy and accountability, governance, management, financing, relevance, research and development, and regional collaboration.

These trends call into question past research findings that social rates of return to higher education were lower than those for primary and secondary education

With regard to finance, for example, the report notes that finding the funding to bankroll future enrollment expansion is expected to become increasingly difficult. African countries contribute an above-the-world-average 4.5 percent of GDP to education. On balance, nearly 20 percent of this amount is earmarked for higher education, a share that approaches the limit of what is appropriate for low-income countries. At the level of individual institutions, the opportunities for income generation have been largely exploited. Likewise, although substantial gains in revenue generation for higher education have been achieved in many African countries through increased costsharing, the financial possibilities of most families are now being stretched. In consequence, additional resources for higher education are most likely to come from efficiency gains within the tertiary system, from creative partnerships with noneducational institutions, and from innovative methods of revenue raising. 


\section{Relevance Is the Key}

The report repeatedly supports shoring up the quality and relevance of higher education, noting that quality education is more closely associated with economic growth. Record rates of enrollment increase over the past decade have driven down expenditure per student and placed quality at risk. Labor market surveys document employer dissatisfaction with graduate competence, and show high levels of graduate unemployment in a number of countries. Thus, the World Bank cautions that "Though social and political demands press for expansion of public tertiary enrollments, these must be balanced against the need to increase the relevance of education and research, and to encourage the production of the technical skills and applied research capabilities that will promote competitive industries" (p. xxii).

In conclusion, the report posits that tertiary institutions in Africa will need to transform themselves into a different type of educational enterprise: networked, differentiated, and responsive institutions focused on the production of strategically needed human skills and applied problem-solving research. To this end, governments will need to fashion national human resource development strategies that choose and strategically fund a limited number of disciplinary and research areas that directly support national economic goals. Africa's mounting crisis in academic staffing-caused by retirements, brain drain, major diseases and weak recruitment

The report posits that tertiary institutions in Africa will need to transform themselves into a different type of educational enterprise.

incentives-will have to be addressed through an aggressive expansion of national and regional postgraduate programs. Research must be resuscitated through funding incentives and partnerships with the productive sector that lay the groundwork for an eventual national innovation system. Increased autonomy is necessary to enable institutions to innovate and differentiate, while system-oversight bodies hold institutions accountable for their performance in the use of public funds, in part through quality assurance mechanisms. Pedagogical reform may be the most difficult, yet most significant, of the changes foreseen as necessary: interdisciplinary rather than disciplinary perspectives; flexibility in learning; group work instead of lectures; problem solving rather than memorization of facts; practical learning as a complement to theory; learning assessment through project work that demonstrates competence, instead of multiple choice examinations; communication skills; and computer literacy. In the medium term, alternative lower-cost educational delivery models must be devised if access is to increase. These may take the form of lifelong learn- ing, information and communications technology applications to education, online distance education, open-source courses, self-paced learning, and educational gameware. Success in these undertakings would constitute the 2Ist-century version of the African "development university."

\section{The World Bank's Perspective on African Higher Education}

\section{Damtew Teferra}

Damtew Teferra is director for Africa and the Middle East of the Ford International Fellowship Program. He is also director of the Boston College Center for International Higher Education's International Network for African Higher Education. E-mail: teferra@bc.edu.

A ccelerating Catch-up, a 2008 third major installment by the World Bank on higher education in Africa, further liberates the continent from the yokes of the imposed, and most importantly, its own flawed intellectual discourse that gripped the system for a long time.

The report is indeed a welcome boost to several other voices that have always recognized the critical role of higher education on development but is a far cry from the World Bank's position in the past. It now declares "neglecting tertiary education could seriously jeopardize SSA's [sub-Saharan Africa's] longer-term growth prospects, and slow progress toward MDGs, [Millennium Development Goals] many of which require tertiary-level training to implement." This is indeed a major turnaround from the time when higher education was declared a luxury the continent could ill-afford.

The report stresses that each country should map its own course, using its own national development strategy, and drawing lessons of good practice from other countries. It recognizes that the countries in Africa have achieved sufficient diversity in their higher education systems and advises that the World Bank's own analyses and recommendations should be linked to country-specific realities.

\section{Countering Homogeneity: Restraining Egalitarianism}

In the last I5 years, unprecedented growth among private providers, new and upgraded public institutions, and unconventional forms of delivery have expanded the system in Africa considerably. However, with about a 5 percent enrollment rate, higher education on the continent remains elitist.

Differentiation and diversification have not kept pace with dramatic expansion of the system. Most of the for-profit private institutions have focused on limited market-oriented programs, creating homogeneity. Meanwhile, the "flagship" uni- 